\title{
K SÉMANTICE LICHTUNG U HEIDEGGERA
}

V přednášce Konec filosofie a úkol myšlení (1964) píše Heidegger v souvislosti se zavedením výrazu Lichtung: „Das Lichte ve smyslu svobodného a otevřeného nemá jazykově ani věcně nic společného s adjektivem licht ve smyslu hell, ,jasný، "“1 Jazykovědně však panuje a vždy panovala dokonalá shoda v názoru, že německé Lichtung, tj. „mýtina, výsek, světlina“ (ale historicky též „,vymycování, vysekávání“) ${ }^{2}$ etymologicky pochází ze slovesa lichten, jež takto získává aktivní význam „,prosvětlovat“", a to je samozřejmě spojeno s adjektivem licht ve smyslu „světlý, jasný“. To je snad důvodem, proč český překladatel citované přednášky i v těsném sousedství uvedené věty (jež, zdálo by se, takový postup vylučuje) užívá ekvivalent „světlina“, který, jak se zdá, česká odborná veřejnost přijala bez výhrad, a proč kupř́íkladu autoritativní Heidegger Handbuch i ve druhém vydání z roku 2013 spojuje Lichtung s metaforikou světla. ${ }^{4}$ Jak tedy Heideggerovu tvrzení v úvodním citátu rozumět a jak výraz Lichtung překládat či interpretovat?

Němčina disponuje dvěma etymologicky odlišnými slovesy lichten. To druhé, poměrně vzácné a pocházející z dolnoněmeckého nářečí, je skutečně odvozeno od adjektiva licht ve smyslu „lehký“, jež se takto psalo již ve středověkých dialektech, zatímco dnešní licht ve smyslu „světlý, jasný“ mělo v Mittelhochdeutsch tvar lîht. Hlavním významem tu je „zvednout kotvu“, slovník bratří Grimmů (z něhož čerpáme i předchozí informace) však poskytuje podrobnější heslo, jež uvádí dostr. 25 .

1 M. Heidegger, Konec filosofie a úkol myšlení, přel. I. Chvatík, Praha 2006²,

2 Viz např. citát: „Schon im nächsten Jahre nach der Lichtung finden wir, daß sich Gräser zeigen..." E. Thiersch, Ueber den Waldbau mit vorzüglicher Rücksicht auf die Gebirgs-Forste von Deutschland, Leipzig 1823, str. 59.

3 Vedle pasivního významu „být jasný, být světlý“, jenž byl do té doby výhradní.

4 Viz D. Thomä (vyd.), Heidegger Handbuch. Leben - Werk - Wirkung, Stuttgart - Weimar 2013², heslo „Brief über den ,Humanismus““ připravil D. Mende: „Die Lichtmetaphorik legt nahe, dass ein in seinem Sein in Dunkelheit gehülltes Seiendes, sei es Gott oder Götter, umgebende Natur oder eigene Geschichte, vom Sein selbst in eine ,Lichtung ' gestellt, erleuchtet, zum Erscheinen gebracht wird“" (tamt., str. 220). 
klady i pro další úzus (zčásti srovnatelný s latinským levare od levis): slovesa se dá užít i pro verbování lidu do vojska, očistu svědomí nebo vzlétnutí.

Heidegger spojuje výraz Lichtung s tímto druhým lichten cíleně a $z$ hlediska běžného úzu neoprávněně, což de facto o pár řádek výše sám přiznává konstatováním, že „německé slovo Lichtung je z hlediska jazykových dějin kalk z francouzského clairière“, 5 tedy potažmo z clair ve smyslu ,jasný“. Věta citovaná na počátku může - i vzhledem k bezprostřednímu kontextu - snadno vzbudit dojem, že se vztahuje k výrazu Lichtung tak, jak v němčině běžně existuje, ve skutečnosti se ale jedná o přepólování, platné výhradně pro Heideggerův úzus: ${ }^{6}$ Lichtung v tom smyslu, jak výrazu hodlám užívat sám, říká se tu vlastně, nemá mít se světlem a jasností ,,jazykově ani věcně“ nic společného.

Proč pak ale autor volí výraz, který de facto zcela jednoznačně sugeruje souvislost s licht ve smyslu „světlý, jasný“? Zdá se, že zde Heidegger sleduje subtilní a pozoruhodnou strategii. Reálně existující slovo Lichtung je - jak tvrdîn - kalkem, takříkajíc jazykovým vynálezem, vzniklo pod vlivem francouzštiny a je jednoznačně spjato s představou světla a prosvětlování. Slovo Lichtung tak, jak je zavádí, je de facto taktéž jazykovým vynálezem, navazuje ale na velmi starý německý slovní kmen a evokuje nářeční, lidový úzus. (Lze dokonce uvažovat, zda ve hře není i polarita mezi dolnoněmeckým regionem, který mořem nedisponuje, a námořnickým významem, který „druhé“ lichten nese. $)^{8} \mathrm{Je}$ ale běžný význam Lichtung skutečně zamítnut či odvržen? $\mathrm{Na}$ některých místech Heideggerova korpusu ano, ${ }^{9}$ zároveň je ale ne-

5 M. Heidegger, Konec filosofie a úkol myšlení, str. 23.

6 Lze však uvažovat o tom, zda jistý střední člen nezajišt'uje výše zmíněný význam „vymycování, vysekávání“.

7 Souvislost není vyloučena, nepodařilo se mi však pro ni najít žádné doklady, ve slovnících se na ni nepoukazuje. Pokud by se jednalo o Heideggerovu smyšlenku či konstrukci, bylo by to tím pozoruhodnější.

8 Na význam ,zdvihnout kotvu“ Heidegger explicitně upozorňuje v přednášce Zur Frage nach der Bestimmung des Denkens, in: Reden und andere Zeugnisse eines Lebensweges, Gesamtausgabe, 16, vyd. H. Heidegger, Frankfurt a. M. 2000, str. 630: „Lichten gehört zu leicht. Etwas leichtmachen, erleichtern meint: ihm die Widerstände beseitigen, es ins Widerstandslose, ins Freie bringen. Den Anker lichten, besagt: ihn aus dem umschließenden Meeresgrund befreien und ihn ins Freie des Wassers und der Luft heben.“ Viz též následující poznámku.

9 Viz zvl. výrok ze semináře s Eugenem Finkem, konaného v Le Thor: „Haben Lichtung und Licht überhaupt etwas miteinander zu tun? Offenbar nicht. Lichtung besagt: lichten, Anker freimachen, roden. Das bedeutet nicht, daß es dort, wo die 
pochybné, že určitou souvislost mezi Lichtung a Licht Heidegger sugeruje též. ${ }^{10}$

Považuji za věrohodné, že Lichtung ve smyslu „mýtina, světlina“ má zůstat ve hře jako první a v něčem nutné neporozumění tomu, co Lichtung pro myšlení skutečně znamená. „Francouzská“ Lichtung, etymologicky spjatá s claritas, pak je první deformací „německé“ Lichtung, která sice až do Heideggera v německém úzu neexistovala, lze ji však z jazykového potenciálu němčiny vyzískat. Samo slovo Lichtung ve své dvojznačnosti - a ve zvláštní jednotě obou (neslučitelných) významů ${ }^{11}$ - tak vedle dvou různých obrazů (totiž odlehčování a prosvěcování) sugeruje určité historické vztahy, určité meze vyjadřování, určitou polaritu mezi aktivitou (Lichtung jako výkon zdvihání kotvy, vylehčování, uvolňování) a vnímaným výsledkem (Lichtung jako hotová mýtina, zalévaná světlem a naskýtající se k vidění).

Podle provedené úvahy je překlad „světlina“ vyloučen: první a hlavní z dvojice významů, který má Lichtung nést, tedy „aktivita vyzdvihování, aktivita vymycování", zcela opomíjí. ${ }^{12}$ Lze najít více vyhovující náhradu? Jednu možnost zde nabídnu..$^{13}$ Slovo „výrub“ má své heslo v Příručním slovníku jazyka českého. Ten je registruje jako hornický

Lichtung lichtet, hell ist.“ (M. Heidegger, Seminar in Le Thor, in: týž, Gesamtausgabe, XV, vyd. C. Ochwadt, Frankfurt a. M. 2005², str. 262). Referenci v této a předchozí poznámce udává Pascal David v podhesle „,Lichtung“, ,clairière‘, ,éclaircie“, ,allégie“" pro heslo Lumière, lumières, in: B. Cassin (vyd.), Vocabulaire européen des philosophies. Dictionnaire des intraduisibles, Paris 2004, dostupné na http:// robert.bvdep.com/public/vep/Pages.HTML/\$LUMIERE2.HTM. Davida nutno (přinejmenším formulačně) korigovat pouze v tom, že první větou vyvolává dojem, jako by německé Lichtung i mimo kontext Heideggerova myšlení „,nemělo se světlem nic společného“.

10 Dobrý strukturovaný přehled referencí ke vztahu mezi Lichtung a světlem viz Francisco J. Gonzalez, Plato and Heidegger. A Question of Dialogue, Philadelphia 2009, str. 314, pozn. 15.

11 Viz např. M. Heidegger, Die Lichtung, in: Besinnung, Gesamtausgabe, 66, vyd. F.-W. von Herrmann, Frankfurt a. M. 1997, str. 108 (,,in der gedoppelten Wesung“, ,in seiner ursprünglichen Einheit").

12 Ve francouzštině přišel François Fédier s novotvarem allégie (od slovesa alléger, ,odlehčit“). Viz M. Heidegger, Apports à la philosophie. De l'avenance, př̀l. F. Fédier, Paris 2013.

13 Zopakujme přitom: jde nám mimo jiné o zdůraznění momentu aktivity, vyjádřeného německým sufixem -ung, a obsahově o zdůraznění podvojnosti viditelného a neviditelného - s důrazem na neviditelné. Jestliže tedy „světlina“ působí představitelněji, zatímco za slovem „výrub“ „nic nevidíme“, není to námitka proti navržené variantě, naopak. 
výraz, označující jednak aktivitu rubání, jednak podzemní prostor získaný rubáním. Spojíme-li „výrub“ vedle dobývání hornin i s kácením dřeva ${ }^{14}$ a využijeme-li etymologicky oprávněnou vazbu jednak kmene „rub-“ s protikladem rub a líc, jednak slova „líc“ se slovem „líce“ ve smyslu tváŕ, tvářnost, ${ }^{15}$ umožňuje nám to chápat „výrub“ jako vznikání či utváření líce (kontrastního vůči rubu) coby prostoru možné tvářnosti. Výrubu je nutno rozumět v dvojznačnosti aktivity (činnost rubání se vykonává uvnitř temné země či hustého porostu) a výsledku, tedy získaného prostoru, volného pole. Vhodná konotace tkví též v tom, že emfaticky chápaný výrub je částí, která nemá celek (nevyrubaná hornina a nevysekaný porost jsou nepřehledné, pro pojetí do celku nepřístupné); tím, do čeho se výrub jakožto výsledek vřazuje, je časový sled vyrubávání jakožto jednání.

Závěrem doplňme dva kratší postřehy. Francouzské slovo clairière, na něž Heidegger výslovně upozorňuje, má metaforický úzus, který v souvislosti s Heideggerem stojí za pozornost, i když se těžko podaří doložit, zda a nakolik si jej Heidegger byl vědom: jedno současné slovníkové heslo, jež metaforickému úzu věnuje zvláštní oddíl, ${ }^{16}$ poukazuje ve výčtu př́kladů na charakteristiku myšlení jakožto hledání mýtin v lese (,Penser, c'est chercher des clairières dans une forêt", Jules Renard, 1894), na zmínku o „velké mýtině vzpomínek“ (,une grande clairière de souvenirs“, Maurice Genevoix, 1934) nebo na výrok o tom, že „na samém dně zoufalství leží bílá mýtina, kde je člověk skoro št’asten“ („,tout au bout du désespoir, il y a une blanche clairière où l'on est presque heureux“, Jean Anouilh, 1934). V roce 1902 přijala označení La Clairière de Vaux anarcho-komunistická kolonie v Essômes-sur-Marne, o jejíž existenci informovala i německá periodika.

Samotné německé Lichtung pak podle všeho prošlo v 19. století jistým vývojem, k němuž alespoň zaznamenávám - aniž bych ji byl s to zcela spolehlivě dokázat - následující hypotézu: výraz Lichtung (resp. Waldlichtung) vzniká kolem roku 1750 a zhruba osmdesát let přetrvává jako takřka výhradně lesnický termín, ${ }^{17}$ od druhé třetiny 19 . století však

14 Tedy s vytěžováním, které je možné chápat jako přestup $k$ vylehčení.

15 Viz hesla „líce“ a „rubati“ in: V. Machek, Etymologický slovník jazyka českého, Praha $1971^{3}$, str. 331 a 523.

16 Trésor de la langue française informatisé, dostupný na http://atilf.atilf.fr/tlfi. html a http://www.cntrl.fr/definition/.

17 Lichtung se též v anatomii používá pro světlost cév, byt' slovníky tento význam nezaznamenávají, a velice ojediněle se najdou i jiná užití, např́íklad pro nasvětlení obrazu. 
přechází do obecného úzu a širríi se v cestopisech i beletrii (vzácného slova např́íklad dosti často používá Theodor Fontane) - stále ovšem v doslovném smyslu „mýtina“. Někdy na přelomu 19. a 20. století se možná začíná etablovat výrazněji figurativní, s reálnou krajinou zcela nesouvisející význam: indicií v tomto směru je (krátkodechá) existence literárního měsíčníku Die Lichtung. Deutsche Monatsschrift (v roce 1907 jej vydávalo drážd’anské nakladatelství Dieterich) nebo fakt, že Willy Pastor v roce 1900 dal svému souboru esejů (na témata výraz tváře, morálka morálky, moderní kult hrdinů či původ literového písma) název Lichtungen. Tím nenaznačujeme, že by snad Heidegger byl těmito okrajovými publikacemi ovlivněn. Výskyt $\mathrm{v}$ titulech $-\mathrm{k}$ němuž by se samožrejmě našly paralely $\mathrm{v}$ textech - uvádíme jen na doklad sémantického posunu, jistě probíhajícího i v kultivované mluvené němčině, z něhož ve své volbě přinejmenším podvědomě vycházel.

Martin Pokorný 